\title{
MODELLING TRAFFIC NOISE LEVEL ON ROADSIDE TRADERS AT WURUKUM MARKET AREA IN MAKURDI TOWN, BENUE STATE - NIGERIA
}

\author{
P. T. Adeke ${ }^{1,}{ }^{*}$, A. A. Atoo ${ }^{2}$ and E. A. Zava ${ }^{3}$ \\ 1, 2,3 Department of Civil EngineEring, University of Agriculture MaKuRdi, Benue State, NiGERIA. \\ E-mail addresses:1adeke.pt@outlook.com,2aondoseeratoo@gmail.com,3aperzava@gmail.com
}

\begin{abstract}
Noise level prediction model was built for road side traders at an open market area of Wurukum market in Makurdi town. One week survey was carried out to measure noise level, traffic volume, vehicles speeds and distances from the edge of road shoulder. The study revealed that roadside traders expose themselves to average noise levels of $82.33 \mathrm{~dB}$ (A), $77.48 \mathrm{~dB}(A)$ and $74.38 \mathrm{~dB}(A)$ at distances of $0 \mathrm{~m}, 5 \mathrm{~m}$ and $10 \mathrm{~m}$ respectively from the edge of roadway. At Om, the noise level was slightly below World Health Organization (WHO) specification of 85dB (A), beyond which noise pollution is hazardous. At 10m, the noise level was above minimum safe level of 55dB (A). The model indicates high level of ambient noise which was attributed to intensive market activities from the background. The model was checked using Chi square test at $5 \%$ level of significance and coefficient of determination $\left(R^{2}=0.7216\right)$ which gave satisfactory results. A strategy of relocation and splitting the market was proposed for local government council's consideration.
\end{abstract}

Key words: Wurukum Market, Ambient noise, Traffic noise, safe noise threshold, roadside traders.

\section{INTRODUCTION}

Urban areas are associated with high level of noise pollution generated from different sources which may include; industrial and commercial activities, traffic flow (vehicle engine and pavement noise), etc. which are promoted by large human population [1]. According to [2], noise pollution in urban cities is considered the third most hazardous type of pollution. Intense noise pollution in urban areas is recognized worldwide as major problem affecting cities livability, and its continued growth is accompanied by increased number of complaints from people exposed to the noise. Negative impacts of high level of noise pollution have accruing and diverse health effects including mental and physical, ranging from annoyance to difficulty in falling asleep or rest deprivation, high blood pressure, hearing loss, cardiovascular problems as well as reduced human productivity in terms of determination and efforts [3 - 9].

In Nigeria, a lot of commercial activities are performed in open markets which are usually wide open spaces with several entrances having less or no control policies. Highways usually pass near, within or around open markets for commuters to travel along, and to enable the hauling of goods in and out of the markets.
Nigeria urban (and indeed suburban) centers have open markets scattered all over where commuters (passers-by) attempt to purchase common products such as food stuffs (snacks or fruits), utensils, toiletries, etc., from hawkers who heave around decelerating and accelerating vehicles around the market area. This creates congested traffic situation which leads to creation of negative transport externalities. An example of a typical open market area in Nigeria is as shown in Figure 1.

The commonest externalities of open markets are excessive noise and air pollution from exhaust pipes and background market activities generated and delivered from within and around the markets area, and high travel costs (time and fuel) caused by traffic congestion [11]. Sources of this noise pollution include; voice from crowded buyers and sellers, loud speakers used for advertising goods and services, vehicular traffic and various mechanical devices employed for production/processing activities within the markets [5, 6].

Buyers, sellers, passers-by and residents within open market areas are exposed to high noise intensity generated from the open markets [1]. 


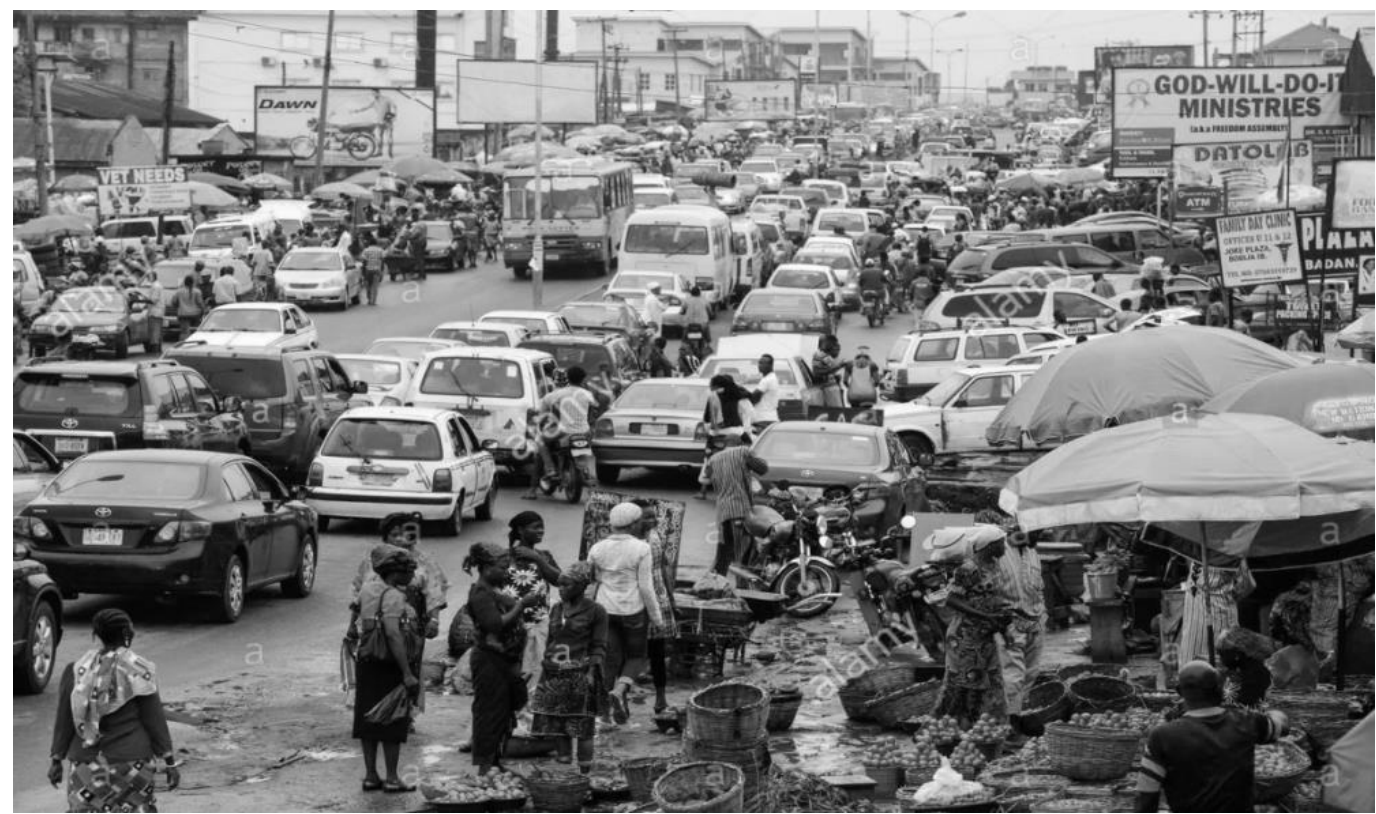

Figure 1: A typical Open Market setting in Nigeria (Source: [10])

This noise has negative impact on the health condition of people who are exposed to it, since it has been established that prolonged exposure to sound louder than $85 \mathrm{~dB}(\mathrm{~A})$ can cause damage to one's hearing system [2]. Therefore, this calls for investigation to establish safe noise threshold for roadside traders and commuters passing within and around open market surroundings as they expose themselves to noise pollution from the markets.

The absence of data on the level of noise pollution emitted around open markets in Makurdi town has posed a challenge to concern persons from knowing the state of health of road side dwellers around open markets. Lack of noise data makes it impossible to ascertain if roadside traders and commuters alike within open market areas are actually at risk regarding the level of noise pollution. This leads to poor planning and traffic control strategies within the town to reduce its menace on people roaming around the market area majorly for petty trading and exposing themselves to noise hazards. This therefore prompted efforts to embark on a study to assess the level of noise pollution emitted on commuters passing through open market areas and roadside traders.

While human population increases rapidly in Nigerian cities, land use and settlement pattern in Makurdi town in recent times is characterized by urban sprawl. Policy makers seem not to understand the relevance of relocating public facilities like open markets to the suburbs to help decongest or reduce high intensity of noise pollution at city centers. This study attempts to confront town planners, transport engineers and policy makers with facts and figures on the magnitude and impact of noise pollution jointly generated by commercial activities and traffic flow around the Wurukum open market in Makurdi town, and also propose strategies to curb impacts of the menace on roadside dwellers.

Generally, noise pollution is defined as excess noise that may be hazardous to human or animal life [2]. Major sources of outdoor noise include automobiles, industrial and commercial activities, power generator plants, aircrafts, trains, etc. [1]. Previous researches stipulate that the major contributor of urban noise is traffic [12 - 14]. The intensive noise pollution in urban areas is associated with the rapid human population growth with corresponding traffic growth rate [15]. Prolonged exposure of human beings to traffic noise is dangerous to their health system as it could damage their hearing capacity, lead to mental illness, heart and behavioural problems, lungs and kidney, etc. Noise pollution has been associated with serious health hazard, with noise-related damage to humans ranging from annoyance to difficulty in falling asleep and high blood pressure $[5-7,13,16]$.

According to [17], World Health Organization (WHO) stipulated that industrial and commercial exposure to noise pollution should not exceed $70 \mathrm{~dB}$ (A) and $85 \mathrm{~dB}$ (A) for residential and, industrial and commercial areas respectively. The report also stated that maximum desirable safe noise level is $55 \mathrm{~dB}(\mathrm{~A})$, when noise level within an environment exceeds $55 \mathrm{~dB}(\mathrm{~A})$, then it may be hazardous to human beings. 


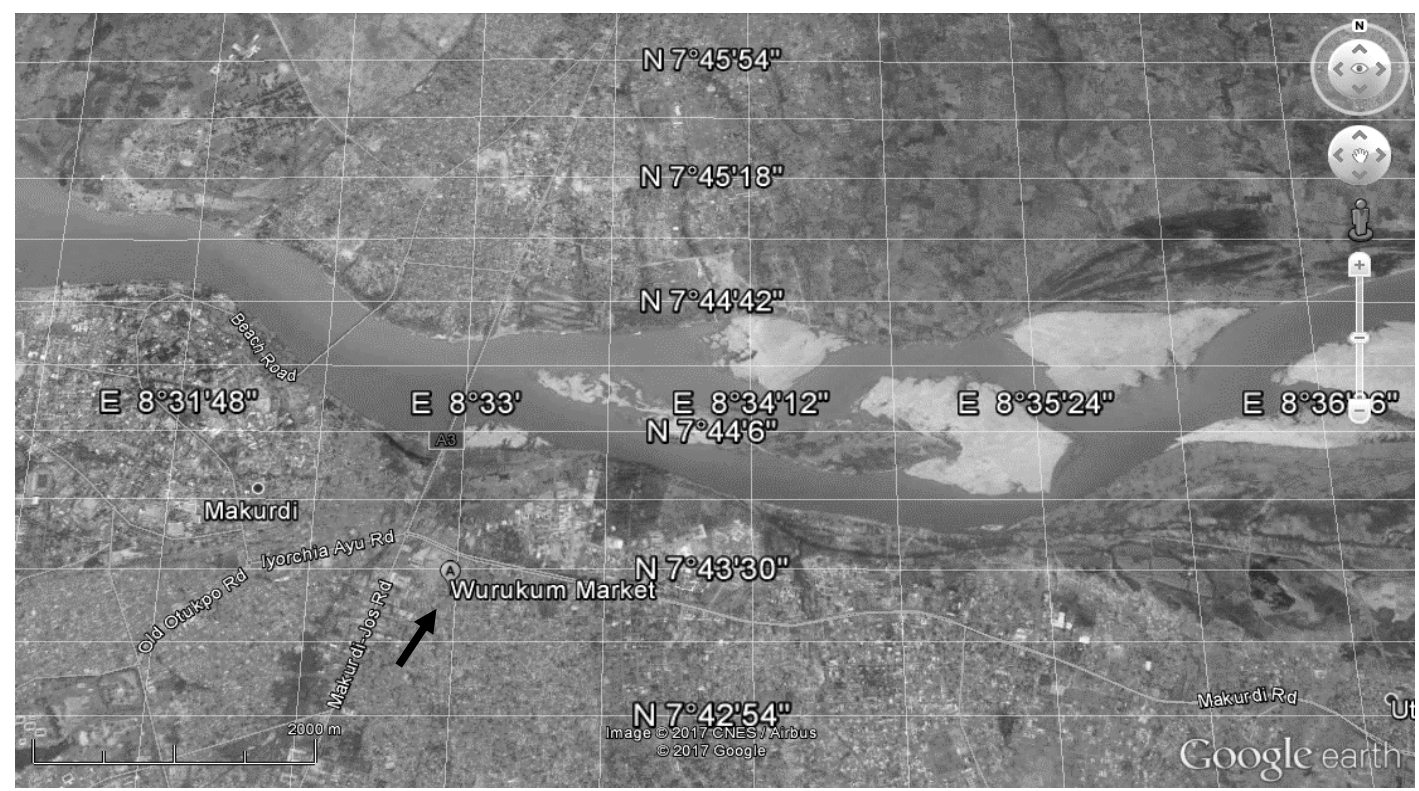

Figure 2: An extraction of Makurdi Map showing the Wurukum Market (Source: [23])

This assertion is subjective to some extents because individual's mode influences the negative impact of noise on them. The Academy of Pediatrics and the National Campaign for Hearing and Health specify that noise level above the threshold of $85 \mathrm{~dB}$ (A) is hazardous to human beings $[5,16]$. Though the National Environmental Board (NEB) and Occupational Safety and Health Act (OSHA) allow human exposure of $90 \mathrm{~dB}(\mathrm{~A})$ for 8-hours in 5-days a week, with a recovery period of 10 hours at $65 \mathrm{~dB}(\mathrm{~A})$ or lower [18].

The increase in human population with corresponding increase in traffic volume and the boost in socioeconomic activities in Nigerian cities heightens the level of noise pollution in the cities [19]. Traffic noise has been identified as a major source of noise pollution in urban areas $[4,13,17]$.

Researchers from different cities around the world have built noise level prediction models to suit their peculiar environmental settings $[13,17]$. A study by [14] reported several noise level prediction models built since 1952, independent variables for the models varied from traffic volume, speed, vehicle composition, distance from the source, period of the day and weather conditions. Example of such models is stated in the Handbook of Acoustic Noise Control which estimated the representative noise level as the $50^{\text {th }}$ percentile of traffic noise $\left(L_{50}\right)$ at given specifications using traffic volume and distance from observation point to the center of traffic lane, other models built estimated equivalent noise level $\mathrm{L}_{\mathrm{eq}}$ and A-weighted equivalent noise levels $\mathrm{L}_{A e q}$. Burgess [20] expressed sound level as a function of the percentage of heavy traffic in the stream.
Research carried out by [13] developed a model for estimating road traffic noise level in Kerala city in India as a function of average speed of vehicles $(\mathrm{km} / \mathrm{h})$, the percentage of three wheelers, the percentage of heavy vehicles and traffic volume (Veh./min). The study concluded that the major source of traffic noise was from heavy vehicle and three wheelers.

In Nigeria, [1] examined elements for environmental noise pollution models and concluded that traffic noise constitutes the largest proportion of urban pollution in urban areas. In the same assertion, [21] and [22] stated that heavy trucks are the major source of urban noise pollution. A study by [1] also examined road traffic noise pollution and its impacts on residents of Ikeja local government area of Lagos state. The study adopted an existing model for estimating the equivalent noise level. The study also concluded that road traffic noise was the major source of noise pollution affecting residents of the Ikeja local government area in Lagos state.

In spite of the negative impacts of noise pollution, lack of awareness for many people has claimed the responsibility while many people are victims to noise pollution hazards in Nigeria [22]. This study therefore aims at modelling traffic noise level on roadside dwellers within the Wurukum market area in Makurdi town.

\section{MATERIALS AND METHODS}

\subsection{Area of the Study}

This study focuses on Wurukum Market area, the most populous open market in Makurdi, Benue state Nigeria. Makurdi is the capital city of Benue state. It falls within 
Nigeria's North-central geopolitical zone. It lies within the Benue trough linking the North and Southern parts of Nigeria. The Wurukum market in Makurdi town is sited on Latitude $7043^{\prime} 27^{\prime \prime}$ and Longitude $8^{\circ} 32^{\prime}$ 59" [23]. Location of the Wurukum Market is as shown in Figure 2.

According to the 2006 population census [24], human population in Makurdi town is estimated as 367,588 people, with a landmass of approximately $800 \mathrm{~km}^{2}$. The area is predominated by civil servants, business men and women, and students of the Benue State University and University of Agriculture Makurdi. Road network in Makurdi metropolis is aligned such that all major routes link to the central rotary intersection called the Wurukum Roundabout situated $72 \mathrm{~m}$ away from the Wurukum open market. Traffic streams within Makurdi town basically consist of private cars, motorcycles (Okada), tricycles, minibuses, taxi cabs and trucks. The minibuses are the dominant means of public transportation in the town which cruise the routes picking up and dropping off passengers frequently, while the Trucks carry agricultural produce and other industrial products such as cement, fuel, timber, water, waste, etc along the same path.

\subsection{Data Collection}

Materials employed for this study included a CEM DT805 sound level meter which measures sound levels in decibels $(\mathrm{dB})$. The sound meter was held in hand at a height of about $1.5 \mathrm{~m}$ with the microphone pointing to the road (source), and measurements taken at $0 \mathrm{~m}, 5 \mathrm{~m}$ and $10 \mathrm{~m}$ at a time from the shoulder edge. It was ensured that sound level measurements were taken in the absence of harsh weather conditions such as high wind and rains. The measured A-weighted equivalent noise level $\left(L_{m-A e q}\right)$ were recorded within intervals of not less than 15 minutes.

A Bushnell speed gun was used for measuring spot speeds of vehicles travelling along the experimental site, vehicles spots speeds were measured by random sampling. A digital stop watch was used for measuring periods and a steel measuring tape used for measuring linear distances from the edge of roadway shoulders to specified locations within the right-of-way. Writing materials such as record sheet, pen, writing pad where used for a manual traffic count.

The Makurdi-Gboko Road which passes near the Wurukum market was divided into segments of not greater than $15 \mathrm{~m}$ from the Wurukum road intersection. The choice of these locations is because of high traffic volume within surroundings of the Wurukum open market.
A one week manual traffic count on both lanes of the highway, noise level measurements, vehicles spot speeds and linear distances from noise sources were measured. Measurements lasted between 12:00 Noon to 5:00 pm per day, presumed to be the peak period for commercial activities at the Wurukum market.

\subsection{Data Analysis}

Data collected during the field work were analyzed using descriptive statistics, and linear regression model built using Statistical Product for Service Solution (SPSS) software, and the model was tested for fitness using chi squared test statistic and coefficient of determination value.

\section{RESULTS AND DISCUSSION}

The descriptive statistics of analyzed data for noise levels at $0 \mathrm{~m}, 5 \mathrm{~m}$ and $10 \mathrm{~m}$ from the roadway shoulder are as shown in Table 1.

From Table 1, the mean noise level at $0 \mathrm{~m}$ is relatively higher than $5 \mathrm{~m}$ and $10 \mathrm{~m}$, with $10 \mathrm{~m}$ having relatively lesser noise level among the three locations considered. This is attributed to the fact that noise level is inversely proportional to linear distance from the sound source. Figures 3 and 4 are scatter plots of measured noise level against vehicles speeds and traffic volumes respectively.

These figures reveal that there is noticeable increase in noise level with increase in vehicle speeds and traffic volume respectively. This agrees with findings of other researches such as [1] and [13].

Table 1: Descriptive Statistic of Data

\begin{tabular}{lccc}
\hline \multirow{2}{*}{\multicolumn{1}{c}{ Parameters }} & \multicolumn{3}{c}{ Values at Distances } \\
\cline { 2 - 4 } & $0 \mathrm{~m}$ & $5 \mathrm{~m}$ & $10 \mathrm{~m}$ \\
\hline Sample Size & 49 & 48 & 48 \\
Range (dBA) & 18.4 & 7.9 & 15.2 \\
Mean (dBA) & 82.327 & 77.481 & 74.383 \\
Variance (dBA) & 6.6203 & 2.9952 & 8.1989 \\
Std. Deviation (dBA) & 2.573 & 1.7307 & 2.8634 \\
Coef. of Variation(dBA) & 0.03125 & 0.02234 & 0.03849 \\
Standard Error (dBA) & 0.36757 & 0.2498 & 0.41329 \\
Skewness(dBA) & -3.3312 & 0.32427 & 0.99198 \\
Kurtosis(dBA) & 18.191 & -0.2103 & 2.212 \\
Min. (dBA) & 68.3 & 73.7 & 68.30 \\
Median (dBA) & 82.5 & 77.45 & 74.15 \\
Max. (dBA) & 86.7 & 81.60 & 83.50 \\
\hline
\end{tabular}

Figure 5 shows the relationship between noise level and linear distance between the sound meter and noise source point. 


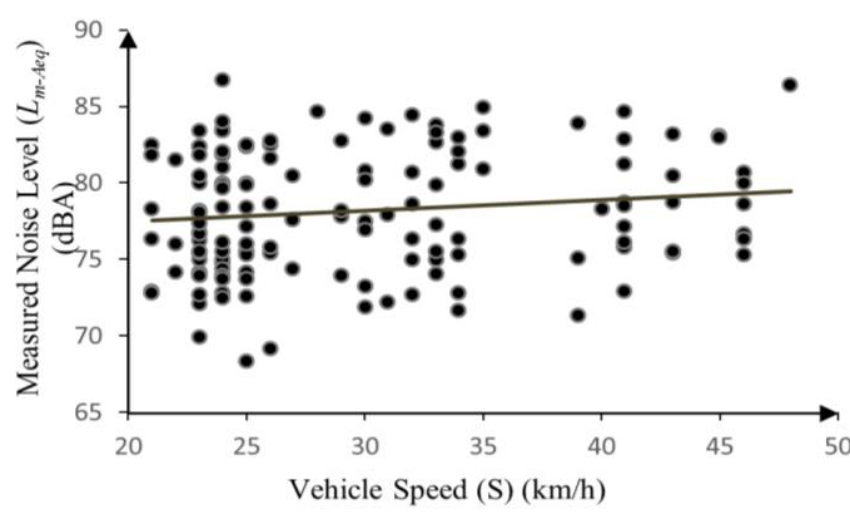

Figure 3: Variation of Noise Level with Vehicle Speed

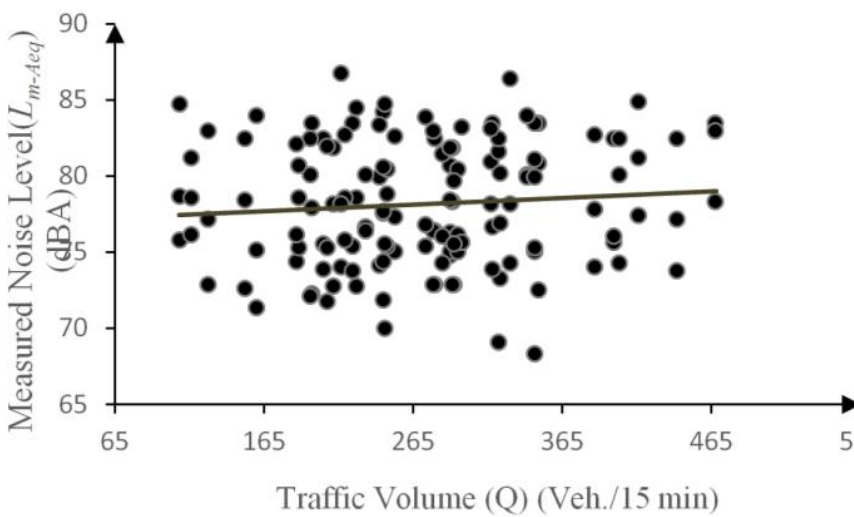

Figure 4: Variation of Noise Level with Traffic Volume

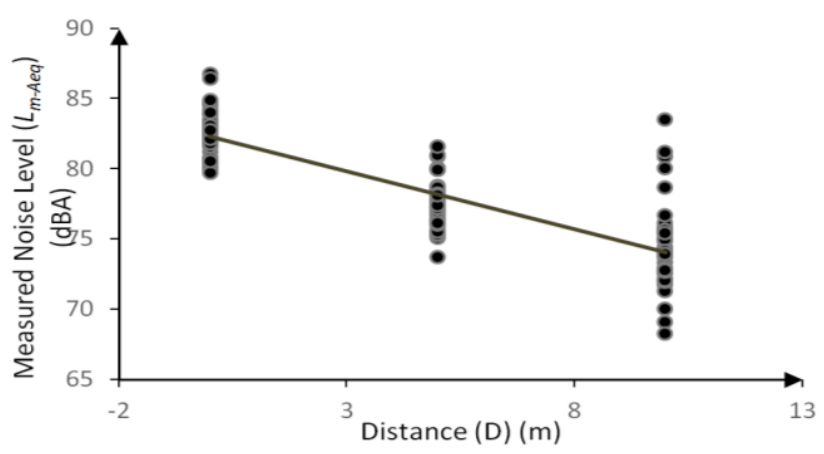

Figure 5: Variation in Noise level with Distance

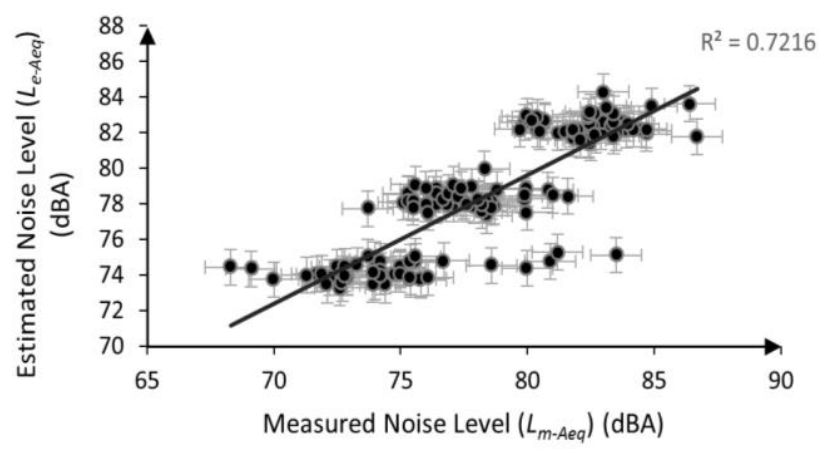

Figure 6: Model Validation

Figure 5 indicate that average noise level at the edge of the roadway which is usually the position where roadside hawkers pause for petty trading is significantly high, approaching the threshold of
$85 \mathrm{~dB}(\mathrm{~A})$ at $0 \mathrm{~m}$ spot, and reduced below $75 \mathrm{~dB}(\mathrm{~A})$ as the distance increases to $10 \mathrm{~m}$. This implies that noise level is inversely proportional to distance between source and measuring instrument.

\subsection{Noise Level Prediction Model}

The linear multiple regression equation for estimating the A-weighted equivalent noise level ( $\left.L_{e-A e q}\right)$ obtained from data analysis using SPSS is as given in Equation 1.

$L_{e-A e q}=79.282+0.006 \times \mathrm{Q}+0.0495 \times \mathrm{S}-0.815 \times \mathrm{D}$

where, $Q$ is the volume of vehicles in both directions (Veh./15 min), $\mathrm{S}$ is spot speed of vehicles $(\mathrm{km} / \mathrm{h}$ ) and D is distance from edge of shoulder of the roadway. The Coefficient of determination $\mathrm{R}^{2}$ of the built model was 0.722 (Adj. $R^{2}=0.716$ ). The Chi squared test statistical function in Microsoft excel was used to check for fitness of the model at $5 \%$ level of significance and 143 degree of freedom $\left(\chi_{\text {Cal }}^{2}=8.3585, p=0.05, \chi_{\text {Table }}^{2}=171.907\right)$. Results indicate that there is no statistically significant difference between the measured ( $\left.L_{m-A e q}\right)$ and estimated ( $\left.L_{e-A e q}\right)$ A-weighted equivalent noise levels. This implies that the built model satisfies its purpose correctly. A scatter plot of measured $\left(L_{m-A e q}\right)$ and estimated $\left(L_{e-A e q}\right) \mathrm{A}$-weighted equivalent noise levels is as shown in Figure 6.

This plot tests the fitness of the model, the clustered points indicate the three major distances away from road shoulder considered by the study $(0 \mathrm{~m}, 5 \mathrm{~m}$ and $10 \mathrm{~m}$ ) with the furthest location having least noise level and vice versa. The error bars also show limit of accuracy in the vertical- and horizontal-directions offered by the test. The coefficient of determination $\mathrm{R}^{2}$ of the regression line shows a strong relationship between estimated output and measured values with a probability of $72.16 \%$ for estimating noise levels accurately. This equation can be used for predicting noise level in a two lane highway. The constant value of 79.282 indicates high magnitude of ambient noise level generated from people's activities and machine operations at the open market. The relatively high constant value shows that ambient noise at the study site is the major constituent of noise pollution. The positive sign of coefficients for traffic volume and vehicle speed shows incremental effects of the variables to the estimated noise level, while the negative values for distance variable indicates a decreasing impact on noise level.

It is obvious that roadside traders heaving around decelerating and accelerating vehicles at the Wurukum market area expose themselves to noise pollution level above the WHO recommendation for safety of $55 \mathrm{~dB}(\mathrm{~A})$. 
Table 2: Noise Pollution control Strategy for Wurukum Market

\begin{tabular}{|c|c|c|}
\hline Strategy Vision & Strategy Element & Policy Instrument \\
\hline \multirow{3}{*}{$\begin{array}{l}\text { To reduce noise level to safe limit at } \\
\text { the Wurukum Market Area in } \\
\text { Makurdi Town }\end{array}$} & Develop Satellite Towns & $\begin{array}{l}\text { - Allocate subsidized plots at suburb } \\
\text { - Build basic social amenities } \\
\text { - Introduce Tax }\end{array}$ \\
\hline & Introduce BRT System & $\begin{array}{l}\text { - Regulate fare and frequency } \\
\text { - Develop BRT facilities } \\
\end{array}$ \\
\hline & Relocate Market to suburb & $\begin{array}{l}\text { - Split Market to suburb } \\
\text { - Separate Markets from highways }\end{array}$ \\
\hline
\end{tabular}

Though the average highest noise level in this study is less than $85 \mathrm{~dB}$ (A) which is the hazardous threshold, the anticipated increase in vehicular volume in Makurdi town guaranteed higher noise level in the near future.

\subsection{Policy Framework}

In order to proffer sustainable solution to the high noise level emitted at the Wurukum market area to achieve a livable city, this research proposed a strategy with strategy elements and policy instruments for government's implementation as shown in Table 2 .

This strategy aims at boosting the development of suburb areas so as to shift huge human population residing at town center to outskirt. This is to help reduce human concentration at the town center which leads to high noise level at the open market area. The strategy requires facility development at the suburb and provision of efficient transport services that could connect town center and the suburb so as to satisfy dweller's needs. Thereby, ensuring equity and discouraging migration since both areas are livable.

It is believed that the implementation of this strategy would proffer sustainable solution to the high level of noise pollution at the Wurukum market area of Makurdi Benue state.

\section{CONCLUSION AND RECOMMENDATIONS}

\subsection{Conclusion}

This study has established that the noise pollution level at the Wurukum market area is higher than the safe threshold of $55 \mathrm{~dB}(\mathrm{~A})$ as specified by WHO within a distance range $0 \leq$ distance $\leq 10 \mathrm{~m}$ from the edge of the roadway shoulder. Based on statistical checks, the built model for predicting noise level at roadside within Wurukum market area is accurate.

The relatively high average noise level traders around the Wurukum market area are exposed to are; 82.33dB(A), $77.48 \mathrm{~dB}(\mathrm{~A})$ and $74.38 \mathrm{~dB}(\mathrm{~A})$ at distances of $0 \mathrm{~m}, 5 \mathrm{~m}$ and $10 \mathrm{~m}$ respectively from the edge of the shoulder, which is unsafe and hazardous to their health as they spend days trading by roadside. It can therefore be concluded that, road side hawkers are liable to be affected by medical problems associated with exposure to high noise pollution. This then calls for quick intervention before the noise level at the site reaches threshold of $85 \mathrm{~dB}(\mathrm{~A})$ which is a dangerous limit for human beings. The study proposed a sustainable strategy of relocating to outskirt and splitting the existing market into smaller units, which can help curb the menace of imposing intensive noise pollution on Makurdi populace dwelling around the Wurukum open Market area.

\subsection{Recommendations}

The following recommendations are made;

i) Road side dwellers should avoid staying near travelling vehicles for a long period of time on daily bases within large open market areas to avoid been affected by noise pollution.

ii) Consideration of other variables such as wind direction, temperature, humidity and vehicle composition and status (engine grade) are recommended to authenticate this model.

iii) The proposed strategy of splitting and relocating the large Wurukum market to suburb, and allocation of plots at the said area at subsidized rates by the government would help shift the population of the market to the suburb thereby reducing the noise pollution associated with the concentrated huge population. In view of this, provision of basic social facilities at the new site would make life more livable for the populace.

\section{REFERENCES}

[1] Onuu, M. U. "Environmental Noise Control: Review and Assessment of Theories and Models", Nigeria Journal of Physic, Vol. 11, pp. 91-96, 1999.

[2] World Health Organization (WHO). "United Nations Road Safety Collaboration", A Handbook of Partner Profiles, World Health Organization, Geneva, 2005.

Vol. 37, No. 1, January 2018 
[3] Ahmad, J., Abbas, A. and Reem, S. "Evaluation of Traffic Noise Pollution in Amman", Jordan Environmental Monitoring and Assessment, Vol. 120, No. 1-3, pp. 499-525, 2006.

[4] Anomohanran, 0. "Evaluation of Environmental Noise Pollution in Abuja, the Capital City of Nigeria", International Journal of Research and Reviews in Applied Sciences, Vol. 14, No. 2, pp. 470 - 476, 2013.

[5] Essandoh, P. K. and Armah, F. A. "Determination of Ambient Noise Levels in the Main Commercial Areas of Cape Coast, Ghana". Research Journal of Environmental and Earth Science, Vol. 3, No. 6, pp. 637-644, 2011.

[6] Okoro, R. C., Bassey, D. E. and Umunnah, R. A. "Sound Levels and Spectra at Ikot Uduak (MCC) Timber Market, Calabar, Cross River state, Nigeria", European Scientific Journal, Vol. 12, No. 15, pp. 231 - 239, 2016.

[7] Saadu, A.A., Onyeonwu, R.O., Ayorinde, E.O. and Ogisi, F.O. "Road Traffic Noise Survey and Analysis in Some Major Urban Centers in Nigeria". Journal of Noise Control Engineering, Vol. 46, No. 4, pp. 146-158, 1998.

[8] Schiller, P. L., Bruun E.C. and Kenworthy, J. R. An introduction to sustainable transportation. Taylor \& Francis Ltd., London. 2010.

[9] World Health Organization (WHO). "Night Noise Guidelines for Europe", WHO Regional Officer for Europe, Denmark, 2009.

[10] Alamy Ltd.: Alamy Stock Photo Nigeria Oyo State Ibadan Crowded Main Road and Market Area. www.alamy.com/stock-photo-nigeria-oyo-stateibadan-crowded-main-road-and-market-areahauptstrasse-144222400.html (2017). Accessed on July 6, 2017.

[11] Ugwuanyi, J. U., Ahemen, I. and Agbendeh, A. A. "Assessment of Environmental Noise Pollution in Markurdi Metropolis, Nigeria", Zuma Journal of Pure and Applied Science, Vol. 6, No. 2, pp. 134138, 2004.

[12] Al-Mutairi, N., Al-Rukaibi, F. and Koushki, P. "Measurement and Model Calibration of Urban Traffic Noise Pollution", American Journal of Environmental Sciences, Vol. 5, No. 5, pp. 613 617, 2009.

[13] Anila, C. and Bino, I. K. "Modelling of Road Traffic Noise -Proceedings of International Conference on Energy and Environment - (ICEE 2013)", International Journal of Innovative Research in Science, Engineering and Technology, Vol. 2, No. 1, pp. 125 - 130, 2013.
[14] George, D. M. and Okeke, P. N. "Applying Mathematical Modeling for Predicting Urban Road Traffic Noise Levels in Port Harcourt Metropolis, Nigeria", Advances in Applied Science Research, Vol. 6, No. 7, pp. 230 - 237, 2015.

[15] Oluwasegun, O. O., Onuu, M. U. and Oyenekan, E. O. "Study of Road Traffic Noise Pollution and Impacts on Residents of Ikeja Local government area of Lagos state, Nigeria", International Journal of Scientific \& Engineering Research, Vol. 6, No. 5, pp. 1108 - 1117, 2015.

[16] Armah, F.A., Odoi, J. O., Yawson, D. O., Yengoh, G. T., Afrifa, E. K. A and Pappoe, A.N.M. "Mapping of Noise Risk Zones derived from Religious Activities and Perceptions in Residential Neighborhoods in the Cape Coast Metropolis, Ghana", Journal of Environmental Hazards: Humanity and Policy Dimension, Vol. 9, No. 4, pp. 358 - 368, 2010.

[17] Adejobi, O. S. "Spatio-temporal Analysis of Noise Pollution levels in Lagos State: oshodi-Agege route experience", European Journal of Globalisation and Development research, Vol. 5, No. 1, pp. 266 - 286, 2012.

[18] Olayinka, O. S. and Abdullahi, S. A. "A statistical Analysis of the Day-time and Night-time Noise Levels in Ilorin Metropolis, Nigeria", Trends in Applied Sciences Research, Vol. 3, No. 3, pp. 253266, 2008.

[19] Asenime, C., Mobereola, D., Ege, E., Alawa, S. and Thompson, U. N. "Spatial Variations in Traffic Induced Noise Level at Iyana-Ipaja/Ikotun Traffic Corridor", America Journal of Social Issues and Humanities, Vol. 5, No. 2, pp. 444 452, 2015.

[20] Menkiti, A. I. "Analysis of Noise bother by Survey Method", Global journal of pure and applied sciences, Vol. 7, No. 3. pp. 37 - 44, 2001.

[21] Piccolo, A., Plutino, D. and Cannistraro, G. "Evaluation and Analysis of the Environmental Noise of Messin, Italy", Applied Acoustics, Vol. 66, No. 40, pp. 447-465, 2005

[22] Anomohanran 0., Iserhien-Emekeme, R. and Emekeme, O. L. "Environmental Noise Assessment Study of Agbor Metropolis in Delta State", Advances in Natural and Applied Sciences Research, Vol. 2, No. 1, pp. 168-174, 2004.

[23] Google Earth “Google Maps Inc.", 2017.

[24] NPC. "National Population Commission" Federal Republic of Nigeria Official Gazzette, 94, No. 24, 2006. 